\title{
EFFECTIVENESS OF NATURAL GAS TRANSPORTATION BY SEA AT APPLICATION OF HIGH PRESSURE WELDED CYLINDERS
}

\author{
B.E. PATON, M.M. SAVITSKY, A.M. SAVITSKY and A.A. MAZUR \\ E.O. Paton Electric Welding Institute, NASU \\ 11 Bozhenko Str., 03680, Kiev, Ukraine. E-mail: office@paton.kiev.ua
}

\begin{abstract}
The paper gives an assessment of technical and economic capabilities of natural gas transportation by sea, allowing for modern gas carrier design, conditions of their loading and unloading and itinerary. Prospects for application of container version of gas transportation into Ukraine are shown. Preparation period before start of gas supply is shortened to 6 months, as manufacture of light-weight car cylinders and gas pipes has already been mastered in Ukraine. Furtheron, it is recommended to envisage construction and application of specialized gas carriers fitted with long metal-plastic cylinders, which are comparable with short pipelines, that allows reducing the strength margin to 1.75. As a result, cylinder metal content is reduced, and volume of transported gas is increased. Application of high-strength steels of 30KhGSA type to develop such cylinders is promising. 22 Ref., 5 Tables, 7 Figures.
\end{abstract}

Keywords: sea transportation of natural gas, metal-plastic cylinders, long cylinders, high-strength steels, welding with higher heating rate, activating fluxes, economic indices

Welding is an energy-dependent process. Its development is inseparably linked to solving the problems of energy carrier supply, particularly natural gas, which by its energy and ecological characteristics, as well as strategic reserves, surpasses all the currently available energy carriers $[1,2]$.

Ukraine, having the most developed gas-transportation system in Europe, experiences a high shortage of gas. Ukraine's traditional local sources can now cover only one third of its needs [2]. Searching for new traditional deposits on the land and on the shelf involves deep-hole drilling and requires development of engineering facilities. Nontraditional sources - gas-bearing shale, coal beds and other dense collectors have not been well enough studied, either in terms of gas content or risks and, therefore, also require considerable financial and time expenses [2]. Technology of using renewable gas sources has local application so far, the evidence of which is rapid expansion of disposal dumps.

Gas-hydrates have a special place among nontraditional methane sources. They contain up to $70 \%$ of its total world deposits, and in Black Sea economic zone of Ukraine - up to $10^{14}$ $10^{15} \mathrm{~m}^{3}$ [3]. However, commercial production of gas-hydrates has not been mastered yet, and its development is conducted with extreme care be- cause of the risk of violation of ecological equilibrium at the sea floor and methane outburst in hear-earth atmosphere.

Investment proposed by PRC in the amount of 3.4 bln USD for construction of synthetic gas plants of the total capacity of about $10 \mathrm{bln}^{3} /$ year in Donetsk, Lugansk and Odessa regions, as well as 3 bln USD for construction of a superport with oil and gas terminals, will not speed up solution of gas problems, either. The latter coincides with the intentions of Ukrainian gas companies to diversify gas supply through external purchases of liquefied natural gas (LNG). However, construction of receiving terminal for LNG requires not only high financial and time expenses, but also long-term contracts to ensure uninterrupted gas supply. Ukraine does not have any of that, just as it does not have the normative-legal basis for construction of a terminal for LNG receiving and processing.

Technology of supply of compressed natural gas $(\mathrm{CNG})$ is more mobile and less costly.

Current researchers of gas supply problems demonstrate [4-7] that at average distances (up to 3000 nautical miles) and sufficient capacity $\left(\geq 12 \mathrm{mln} \mathrm{m}^{3}\right.$ ) of high-pressure cargo system of gas carriers, CNG technology can be more readily mastered and cost-effective. Compressed gas does not require such deep purification, or expenses for its liquefying, storage and re-gasification (Table 1, Figure 1) [7]. And its receipt does not require high-tech and expensive coastal facilities. Gas loading can be performed directly from GTS 


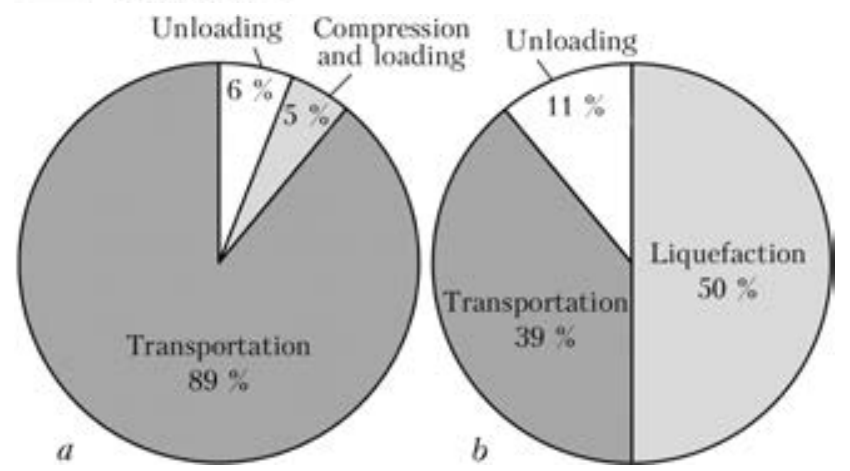

Figure 1. Price components for CNG $(a)$ and LNG (b) projects

or wells on the shelf, and unloading - through GTS into gas storages. As a result, a tradeoff variant is possible, when application of a floating tanker-regasifier and underwater buoy of submerged turret loading type taken out into the sea beyond the port water area, will allow receiving both liquefied and compressed gas. This solution allows application of both LNG and CNG technologies, with the only difference that LNG first passes through re-gasifier to GTS and CNG is supplied directly. Such a solution of gas supply problem will allow using price fluctuation

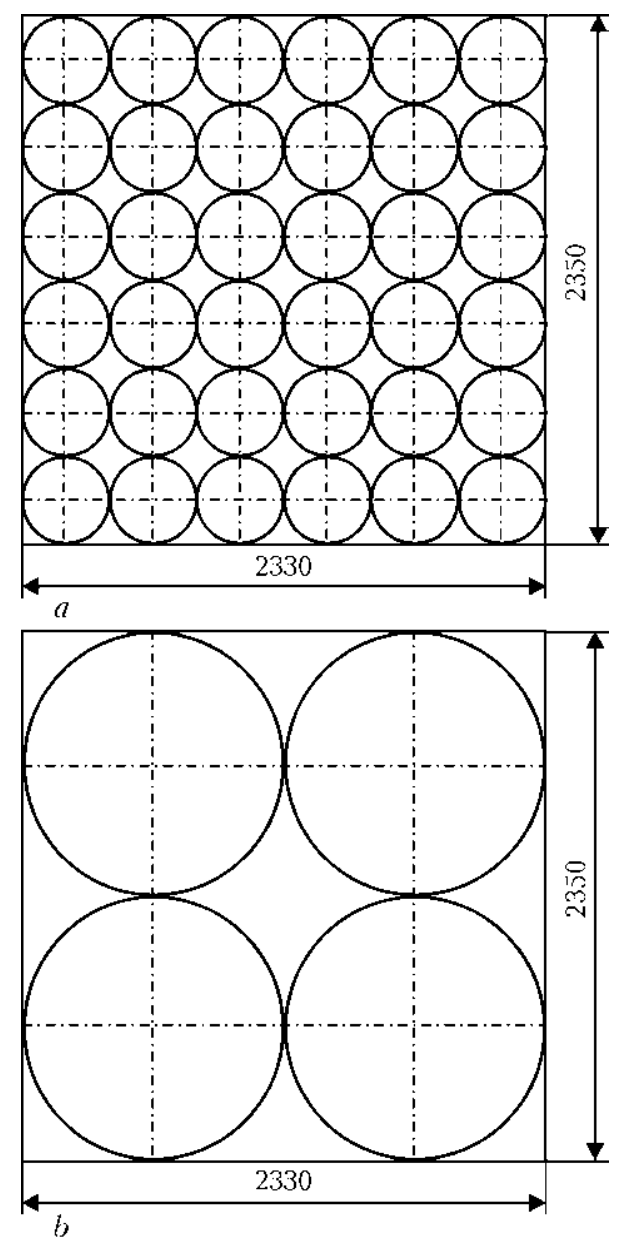

Figure 2. Schematic of container fitting with high pressure cylinders (horizontal location): $a-390 \mathrm{~mm}$ diameter; $b-$ $1020 \mathrm{~mm}$
Table 1. Comparison of gas prices depending on distance (data of University of Houston) [7]

\begin{tabular}{||c|c|c|c|}
\hline \multirow{2}{*}{ Distance, miles } & \multicolumn{3}{|c|}{ Kind of gas, USD $/ 1000 \mathrm{~m}^{3}$} \\
\cline { 2 - 4 } & Liquefied & Compressed I & Compressed II \\
\hline 500 & 355 & 272 & 272 \\
\hline 1000 & 365 & $274-284$ & $282-290$ \\
\hline 1500 & 375 & $306-310$ & $315-326$ \\
\hline 2000 & 385 & $330-337$ & $311-362$ \\
\hline 2500 & 395 & $344-390$ & $350-398$ \\
\hline 3500 & 425 & $408-443$ & $398-434$ \\
\hline 5000 & 465 & $484-549$ & $470-543$ \\
\hline
\end{tabular}

Note. I - gas volume of $0.91 \cdot 10^{6} \mathrm{~m}^{3}$; II $-0.15 \cdot 10^{6} ; 1000 \mathrm{~m}^{3}$ gas cost, USD: 75 , liquefaction -40 , gasification -40 .

in the spot market and accelerate diversification of supply.

More over, development of CNG technology will allow faster mastering of Black and Azov Sea shelf in production of traditional natural gas from small and medium-sized deposits, from which it is not cost-effective to lay pipelines of about $9 \mathrm{mln} \mathrm{UAH} / \mathrm{km}$ cost to the coast. Application of CNG-carriers (vessels or barges) provides a cardinal solution of the problem of gas supply to the shore. Trying this technology out in the USA in 1960s at large distances, however, turned out to be less effective, compared to LNG. However, the situation is changing cardinally, in connection with shelf mastering and closer located users entering the market.

The objective of this work was evaluation of technical and economic capabilities of natural gas transportation by sea, allowing for design features of cargo system of modern gas carriers, conditions of their loading-unloading and itineraries.

Investigations of technical capabilities and cost-effectiveness of application of CNG technology in Ukraine point to two variants of its realization. The first is based on application of currently available container carriers, which can be converted into gas carriers, fitting their containers with welded cylindrical metal-plastic cylinders (Figure 2) [8, 9]. Technical characteristics of 20 and 40 feet sea containers and weight and dimensional characteristics of the cylinder components are given in Table 2 .

Container variant of gas transportation in Ukraine allows reducing to 6 months the preparatory period for the start of gas supply, as manufacture of light-weight car cylinders and gas pipes has already been mastered in Ukraine. For the future, however, construction and use of 
Table 2. Technical characteristics of 20 and 40 feet sea containers and weight-and-dimensional characteristics of cylinder components (liner material is unidirectional glass-reinforced plastic)

\begin{tabular}{|c|c|c|c|c|c|c|c|c|}
\hline \multirow{4}{*}{ Shell material } & \multirow{4}{*}{$\begin{array}{c}\text { Cylinder } \\
\text { diameter, } \\
\mathrm{mm}\end{array}$} & \multirow{4}{*}{ Characteristics } & \multicolumn{6}{|c|}{ Working pressure, MPa } \\
\hline & & & \multicolumn{2}{|c|}{20} & \multicolumn{2}{|c|}{25} & \multicolumn{2}{|c|}{30} \\
\hline & & & \multicolumn{6}{|c|}{ Container size, feet } \\
\hline & & & 20 & 40 & 20 & 40 & 20 & 40 \\
\hline \multirow{7}{*}{$\begin{array}{c}\text { Heat-treated } \\
\text { steel 30KhGSA } \\
\left(\sigma_{\mathrm{t}}=960 \mathrm{MPa}\right)\end{array}$} & \multirow[t]{3}{*}{390} & Cylinder $m / V, \mathrm{~kg} / 1$ & 0.65 & 0.64 & 0.73 & 0.71 & 0.82 & 0.80 \\
\hline & & Weight of container with cylinders, $\mathrm{kg}$ & 15772 & 32232 & 17464 & 35328 & 19336 & 39324 \\
\hline & & Gas volume in container at $20{ }^{\circ} \mathrm{C}, \mathrm{n} . \mathrm{m}^{3}$ & 4176 & 8814 & 5220 & 11018 & 6264 & 13222 \\
\hline & \multirow[t]{4}{*}{1020} & Cylinder $m / V, \mathrm{~kg} / 1$ & 0.64 & 0.64 & 0.71 & 0.70 & 0.81 & 0.80 \\
\hline & & Cylinder weight, $\mathrm{kg}$ & 8856 & 19788 & 9824 & 21644 & 11208 & 24736 \\
\hline & & Weight of container with cylinders, $\mathrm{kg}$ & 11056 & 23688 & 12024 & 25544 & 13408 & 28636 \\
\hline & & Gas volume in container at $20{ }^{\circ} \mathrm{C}, \mathrm{n} . \mathrm{m}^{3}$ & 2770 & 6184 & 3460 & 7730 & 4152 & 9276 \\
\hline \multirow{5}{*}{$\begin{array}{c}\text { X80 steel pipe } \\
\text { GOST } 1078 \\
\left(\sigma_{\mathrm{t}}=640 \mathrm{MPa}\right)\end{array}$} & \multirow[t]{5}{*}{1020} & Cylinder volume, 1 & 3460 & 7730 & 3460 & 7730 & 3460 & 7730 \\
\hline & & Cylinder $m / V, \mathrm{~kg} / 1$ & 0.81 & 0.80 & 0.92 & 0.90 & 1 & 0.99 \\
\hline & & Cylinder weight, $\mathrm{kg}$ & 11160 & 24600 & 12732 & 27828 & 13840 & 30612 \\
\hline & & Weight of container with cylinders, $\mathrm{kg}$ & 13360 & 28500 & 14932 & 31728 & 16040 & 34512 \\
\hline & & Gas volume in container at $20^{\circ} \mathrm{C}, \mathrm{n} . \mathrm{m}^{3}$ & 2770 & 6184 & 3460 & 7730 & 4152 & 9276 \\
\hline
\end{tabular}

modern specialized gas carriers should be envisaged, which have the capability for further improvement of cargo system. A combination of the two projects should be used as an analog here [5], complementing it by our own developments on metal-plastic cylinders [8]. Coselle project envisages winding 156-162 $\mathrm{mm}$ diameter up to 10 miles long pipe into a bundle, that, by the decision of US coast service, can be regarded as a section of floating pipeline with strength margin of 1.75 instead of 2.5. This allows lowering the module weight (one tank), increase by $30 \%$ the number of modules on a vessel, and the total volume of cargo system, respectively.

The project disadvantage is the complexity of bundle manufacturing, which only three to four plants in the world can cope with. Therefore, it is believed to be more rational to use the idea, underlying the «Vortrans» project. The latter envisages laying long cylinders into a sealed cooled hold along the entire ship hull. The project authors propose increasing the capacity of gas carrier cargo system due to cooling the cylinders with gas to $-30{ }^{\circ} \mathrm{C}$. Here, either the cylinder metal content can be lowered, or their capacity can be increased as a result of gas pressure lowering.

However, lowering working temperatures, in addition to energy losses, is known to involve increase of brittleness of high-strength steels, which can provide maximum improvement of weight and dimensional characteristics of cylin- ders. Therefore, it is more rational to apply reinforcement of cylinder bodies by glass-reinforced plastic. This will allow eliminating expenses for cooling at loading and for heating at unloading, reducing their metal content and eliminating the possibility of embrittlement and fragmentation in case of formation of a fatigue or brittle crack. In addition, long cylinders (200$300 \mathrm{~m}$ ) can be regarded as looping (pipeline branches), which, similar to the main pipelines, are allowed to operate with a lower strength margin. Experience of their operation in densely populated regions of many countries has been confirmed many times. Now, having applied successive binding of cylinders, they can be connected into one floating pipeline [9, 10].

Thus, the cargo system of CNG carriers can be improved due to either reducing the wall thickness and, therefore, metal content without changing the working pressure, or increasing the working pressure at unchanged wall thickness and metal content [9].

It is common knowledge that at loading by inner pressure of a cylindrical cylinder with semispherical covers, axial stresses

$$
\sigma_{\mathrm{a}}=\frac{r_{\text {in }}}{2 \delta} \frac{P_{\text {work }}}{\varphi_{\mathrm{w}}} K_{\mathrm{m}}
$$

are 2 times lower than radial stresses

$$
\sigma_{\mathrm{r}} \frac{r_{\text {in }}}{\delta} \frac{P_{\text {work }}}{\varphi_{\mathrm{w}}} K_{\mathrm{m}},
$$




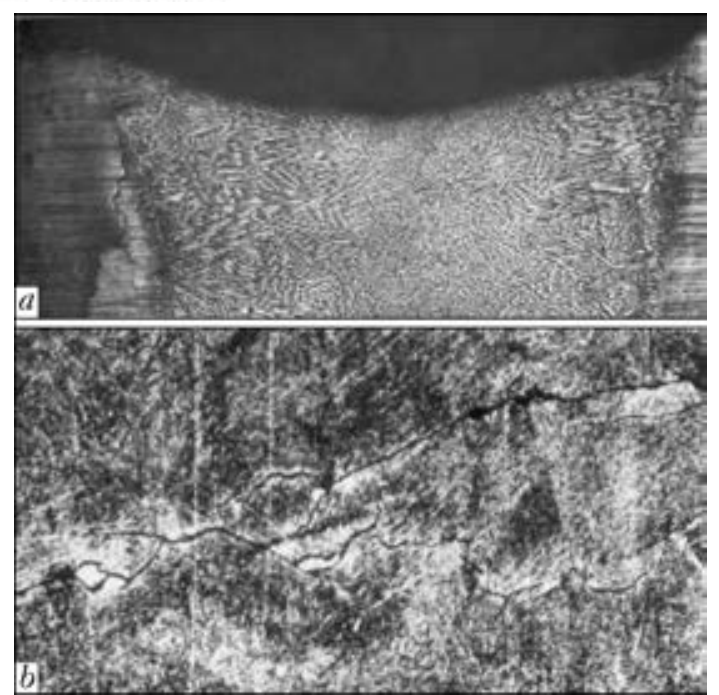

Figure 3. Fatigue cracks in welded joints of 30KhGSA steel: $a$ - welded joint macrosection; $b$ - secondary microstructure of welded joint $(\times 300)$

where $\sigma_{\mathrm{a}}$ and $\sigma_{\mathrm{r}}$ are the axial and radial stresses in cylinder walls, respectively, MPa; $r_{\text {in }}$ is the cylinder inner radius, $\mathrm{mm} ; \delta$ is the wall thickness of cylinder metal body, $\mathrm{mm} ; P_{\text {work }}$ is the working gas pressure in the cylinder, MPa; $\varphi_{\mathrm{w}}$ is the weld strength factor; $K_{\mathrm{m}}$ is the coefficient of strength margin.

Therefore, additional strengthening is required only for the cylindrical part of the body.

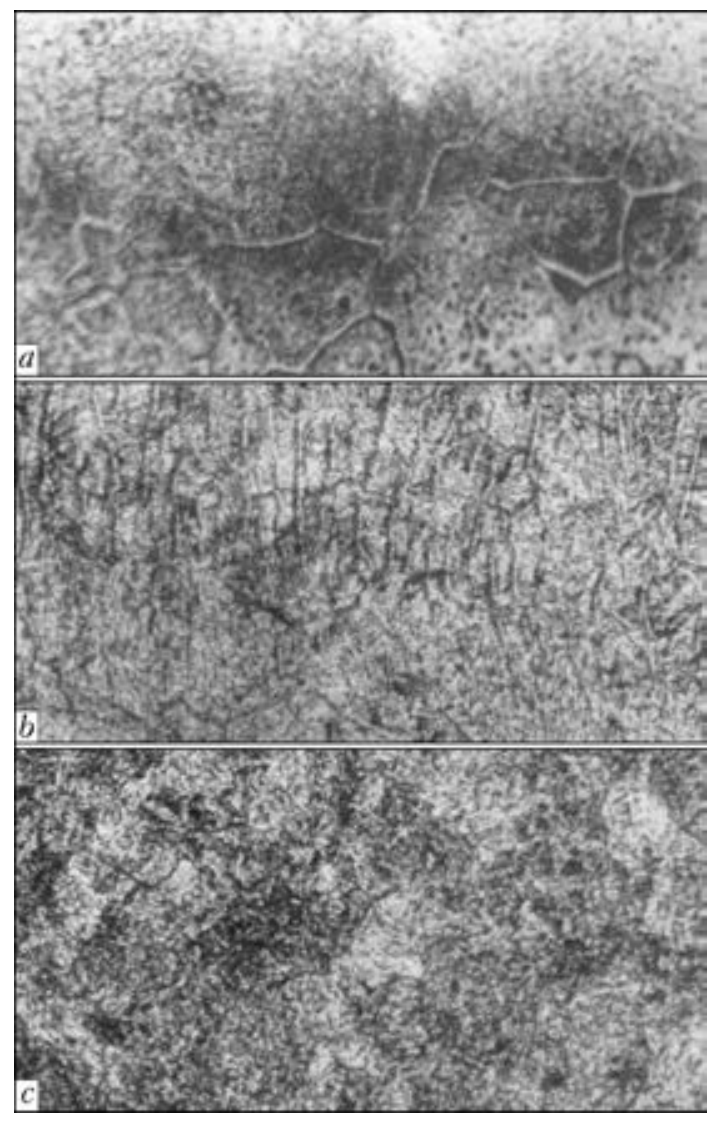

Figure 4. Microstructure $(\times 260)$ of welded joint: $a$ - before quenching; $b$ - after quenching; $c$ - after thermomechanical treatment
Using for this purpose lighter $\left(1.8-2.2 \mathrm{~g} / \mathrm{cm}^{3}\right)$ glass-reinforced plastic, the strength of which is equal to that of steel, it is possible to reduce cylinder weight by $30-40 \%$, doubling its static strength and increasing its cyclic fatigue life 3 to 5 times [8]. The latter is due to lowering of the influence of surface concentrators as a result of their filling by binder.

Modern high-strength steels allow, depending on heat treatment modes, changing strength characteristics from 600 to $2000 \mathrm{MPa}$ [11]. Here, welded joints with welds of identical composition under static loading can have equal strength to that of base metal [12]. The situation changes, however, at low-cycle loading. Fatigue life (number of loading-unloading cycles) of welded joints depends essentially on local stress concentrations and microplastic deformations, as a result of higher, compared to base metal, physical and chemical inhomogeneity, particularly at fusion boundary [13]. Figure 3 gives typical fatigue cracks in overheated region of boundary zone. It is seen that they are related to crystalline structure of metal exposed to thermal cycle of welding. Elimination of unfavourable consequences of this impact required a package of structure improvement techniques, including thermal cycles of welding and subsequent treatment of cylinders, particularly longitudinal welds oriented normal to radial stresses.

It is experimentally established that to ensure the required fatigue life of metal-plastic cylinders with steel bodies [14], it is necessary to achieve metal ductility and toughness values not lower than $\delta_{5} \geq 12-15 \%, \alpha_{\mathrm{n}} \geq 80 \mathrm{~J} / \mathrm{cm}^{2}$. Comprehensive thermomechanical treatment of longitudinal welds, as welded body sections the most vulnerable and sensitive to local stress concentrations, improves their structure (Figure 4), and provides the required combinations of ductility and toughness of welded joint metal, extending the fatigue life of combined cylinders (Figure 5).

At glass roving strength of $940-1180 \mathrm{MPa}$ steel (30KhGSA) and composite shells have quasiequal strength, and at equal thickness after 15,000 loading-unloading cycles they preserve their strength margin $\geq 2.6 \sigma_{\mathrm{t}}$. In case of application of $09 \mathrm{G} 2 \mathrm{~S}$ steel, the strength of which is equal to about $490 \mathrm{MPa}$ [15], to achieve the required strength margin of the cylinder, it is required to increase steel body thickness by almost 2 times, if the reinforcing shell is formed only on the cylindrical part. Reduction of cylinder body wall thickness, as shown by joint investigations of PWI and Institute of Mechanics 


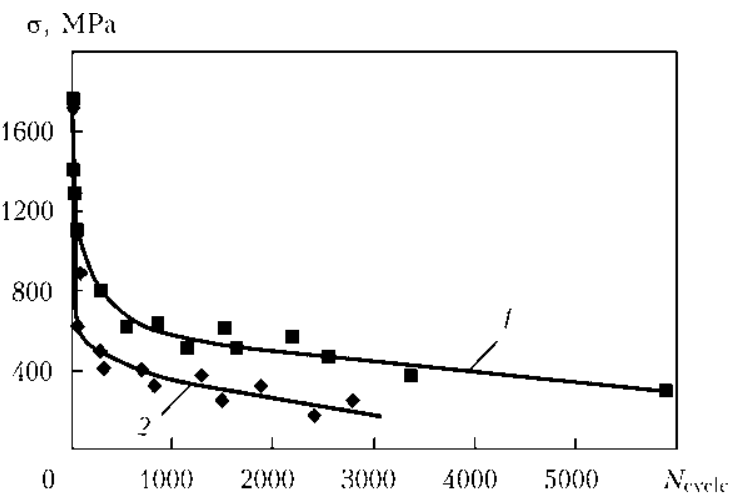

Figure 5. Curves of cylinder performance under cyclic loads: 1 - after thermomechanical treatment; 2 - after heat treatment

of NASU, is achieved by forming a «cocoon» type shell.

It is difficult to realize winding of long cylinders into a «cocoon». Therefore, an optimum solution here can be increase of either pipe wall thickness, or steel strength point in proportion to cylinder diameter (expressions (1) and (2), Figure 6).

High-strength steels of 30KhGSA type, having high $\sigma_{t}$ and $\sigma_{y}$ values, are prone to quenching in air with formation of low-ductile structures that, under certain conditions, can lead to crack initiation in welded joints. It also is important to note that 30KhGSA steel, alloyed by silicon, has almost 2.4 times lower heat conductivity than that of iron [15, 16]. This lowers the intensity of heat removal from the welding zone, and extends the duration of metal staying in high temperature range, that intensifies development of chemical microinhomogeneity of weld metal, lowering metal mechanical properties and its resistance to crack initiation and propagation [12, 17]. Therefore, the rationality of preheating and concurrent heating of $30 \mathrm{KhGSA}$ steel in welding is questionable. More useful, as shown by investigations, is increase of cooling rate above point $A_{(r)}$, and certain slowing of joint cooling at temperatures of completion of austenite decomposition with the purpose of decomposition products self-tempering and increase of their ductility.

Experience of welding and heat treatment of steels of the above group [18-20] confirms that elimination of heating allows forming in the joints fine-grained structures of tempered martensite or bainite-martensite mixture just due to parameters of thermal cycle of welding. One of the methods to solve this problem is application of welding modes with increased $\left(\geq 500{ }^{\circ} \mathrm{C} / \mathrm{s}\right.$ ) rates of metal heating, that is achieved either by increase of energy concentration in the arc, or reduction of heating duration at application of an arc with lower concentration.
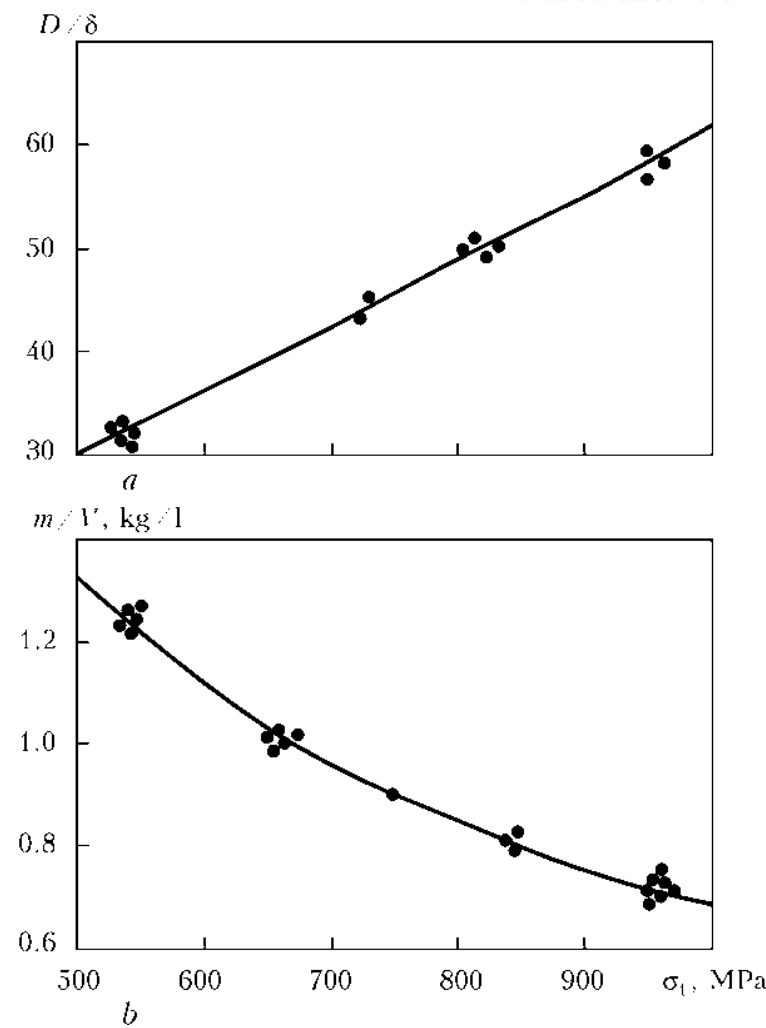

Figure 6. Influence of steel strength on the ratio of pipe diameter to wall thickness $(a)$ and cylinder weight to its volume $(b)$

Activating fluxes are an effective means of increasing heating concentration [21, 22]. Heat power of the arc in consumable-electrode welding usually is $2-3$ times higher than with nonconsumable electrode at the same welding currents. Therefore, in order to obtain an equivalent effect, nonconsumable-electrode welding with activating flux is performed at rates approximately $2-3$ times lower than in gas-shielded consumableelectrode welding with activating flux. Maximum influence on kinetics of structure formation in the first case is achieved at up to $6 \mathrm{~mm}$ metal thickness, when metal heating rates are equal to $\geq 600-700{ }^{\circ} \mathrm{C} / \mathrm{s}$. With increase of metal thickness the rates of heating in nonconsumable-electrode welding with activating flux decrease abruptly, therefore, it is rational to apply gas-shielded consumable-electrode welding with activating flux. It allows welding $10-20 \mathrm{~mm}$ thick metal in one pass with heating rates of $\geq 3000{ }^{\circ} \mathrm{C} / \mathrm{s}$, that essentially reduces the time of metal staying in the region of high temperatures during heating, and also reduces the volumes of overheated metal.

It is known that increase of rates of highstrength metal heating is accompanied by its accelerated cooling and, therefore, quenching with formation of higher hardness zones (Figure 7, curve 1). Metal hardness in the zone here is 1.52 times higher than that of thermally improved base metal. Therefore, for high pressure vessels, 
$I I^{\prime} 0.2$

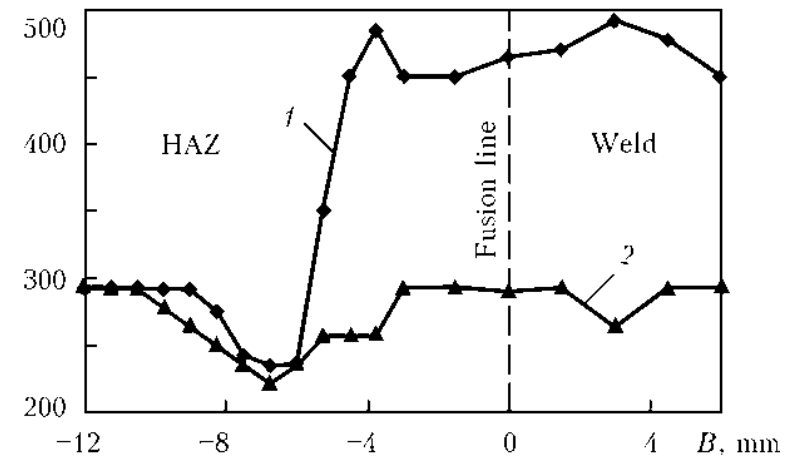

Figure 7. Influence of local tempering on microhardness in weld metal and HAZ: 1 - after welding; 2 - after local tempering

local tempering of welded joints is envisaged, in keeping with the requirements of [14]. Its aim is to achieve maximum leveling of the difference between hardness of metal strengthened to $900-$ $1000 \mathrm{MPa}$ and hardness of weld metal and HAZ (Figure 7, curve 2). Here, as follows from the above Figure, the softening zone practically does not change its characteristics, yet does not go beyond the limits of admissible hardness and strength, i.e. its performance is commensurate with that of base metal. By absolute value metal strength in the softening zone is below base metal strength by just $\leq 10 \%$, and impact toughness here is almost 2 times higher. Studies of stamped covers showed that local lowering of strength margin within the above limits does not influence item performance. Moreover, $15 \%$ increase of work loads at cylinder testing does not reduce their strength margin. This can be the prerequisite for increase of working pressure in the cylinders, at which the design strength margin can be allowed to be lowered to 1.75 . This will permit better use of reserves incorporated in cylinder design due to the fact that minimum values of mechanical properties, obtained at uniaxial tension, are usually assumed in calculations. These values are higher under the conditions of biaxial loading. Characteristics of cylinders with strength margins of 2.5 and 1.75 are shown in Table 3.

Table 3. Cylinder variants for cargo system of specialized CNG-carriers (planned mass of pipelines on the ship is 85.5 thou t)

\begin{tabular}{|c|c|c|c|c|}
\hline \multirow{4}{*}{ Parameter } & \multicolumn{4}{|c|}{$K_{\mathrm{m}}$} \\
\hline & \multicolumn{2}{|c|}{2.5} & \multicolumn{2}{|c|}{1.75} \\
\hline & \multicolumn{4}{|c|}{$\sigma_{\mathrm{t}}, \mathrm{MPa}$} \\
\hline & 640 & 960 & 640 & 960 \\
\hline Pipe typesize & MP1220 $\times 27.06$ & MP1220 × 18.04 & MP1220 × 18.3 & MP1220 × 12.2 \\
\hline Length of pipelines on the ship, $\mathrm{km}$ & 77.2203 & 07.9273 & 106.4463 & 145.0136 \\
\hline
\end{tabular}

Table 4. Technico-economic indices of sea transportation of $10 \mathrm{bln} \mathrm{m}^{3}$ of gas per year to 1 thou $\mathrm{km}$ distance

\begin{tabular}{|c|c|c|c|c|c|c|c|c|}
\hline \multirow{3}{*}{$\begin{array}{c}\text { Aggregate state of gas } \\
1\end{array}$} & \multirow{2}{*}{\multicolumn{2}{|c|}{$\begin{array}{l}\text { Investments, mln USD } \\
\text { (place) }\end{array}$}} & \multicolumn{4}{|c|}{ Operating costs, mln USD } & \multirow{2}{*}{\multicolumn{2}{|c|}{$\begin{array}{l}\text { Sum of expenses in } \\
20 \text { years }[2]+[6] \text {, } \\
\text { mln USD (place) }\end{array}$}} \\
\hline & & & \multicolumn{2}{|c|}{ In 1 year (place) } & \multicolumn{2}{|c|}{ In 20 years (place) } & & \\
\hline & 2 & 3 & 4 & 5 & 6 & 7 & 8 & 9 \\
\hline NGH (crystalline hydrates) & \multicolumn{2}{|c|}{$2644(\mathrm{~V})$} & \multicolumn{2}{|c|}{$606(\mathrm{~V})$} & \multicolumn{2}{|c|}{$12120(\mathrm{~V})$} & \multicolumn{2}{|c|}{$14764(\mathrm{~V})$} \\
\hline LNG & \multicolumn{2}{|c|}{$2030(\mathrm{IV})$} & \multicolumn{2}{|c|}{243 (II) } & \multicolumn{2}{|c|}{4860 (II) } & \multicolumn{2}{|c|}{6890 (III) } \\
\hline $\mathrm{CNG}\left(K_{\mathrm{m}}=1.75\right)$ & \multicolumn{2}{|c|}{1348 (II) } & \multicolumn{2}{|c|}{$210(\mathrm{I})$} & \multicolumn{2}{|c|}{$4200(\mathrm{I})$} & \multicolumn{2}{|c|}{$5548(\mathrm{I})$} \\
\hline $\mathrm{CNG}\left(K_{\mathrm{m}}=2.5\right)$ & \multicolumn{2}{|c|}{1771 (III) } & \multicolumn{2}{|c|}{$282(\mathrm{IV})$} & \multicolumn{2}{|c|}{$5720(\mathrm{IV})$} & \multicolumn{2}{|c|}{$7491(\mathrm{IV})$} \\
\hline CNG (container carrier renting) & \multicolumn{2}{|c|}{$1251(\mathrm{I})$} & \multicolumn{2}{|c|}{270 (III) } & \multicolumn{2}{|c|}{5400 (III) } & \multicolumn{2}{|c|}{6651 (II) } \\
\hline
\end{tabular}

Table 5. Rating of methods of sea transportation of $10 \mathrm{bln}^{3}$ of natural gas per year depending on shipment distance

\begin{tabular}{||l|c|c|c|c|c||}
\hline \multirow{2}{*}{\multicolumn{1}{c|}{ Aggregate state of gas }} & \multicolumn{5}{c||}{ Shipment distance, km } \\
\cline { 2 - 6 } & 620 & 1000 & 2000 & 3000 & 5000 \\
\hline NGH (crystalline hydrates) & V & V & V & V & V \\
\hline LNG & IV & III & II-I & II & II \\
\hline CNG $\left(K_{\mathrm{m}}=1.75\right)$ & I & I & I-II & IV & IV \\
\hline CNG $\left(K_{\mathrm{m}}=2.5\right)$ & III & IV & IV & III & III \\
\hline CNG $($ container carrier renting) & II & II & III & & \\
\hline
\end{tabular}


PWI developed an algorithm and required software, allowing performance of multifactorial technico-economic evaluation of the proposed variants of gas transportation, determination of required capital and operating costs, depending on volume and distance of gas transportation, its aggregate state, vessel size and type of cargo system of gas carriers, navigation water areas, terms of passing straits and channels, port and other charges.

Capital investments included construction of receiving terminal (its coastal and offshore part), and construction of the required number of tankers. Alongside new ship construction, also renting variants were considered, including those with ship refitting and mounting gas transportation system.

The following variants of gas delivery itineraries of different length were considered, including those from off-shore wells in the Azov-Black Sea shelf $(220 \mathrm{~km}))$, within the Black Sea area (Supsa-Feodosia, $620 \mathrm{~km}$ ), variant with going beyond the Black Sea limits: Egypt-Ilyichevsk (1971 km); Skikda-Ilyichevsk (2843 km), Shardzhi-Ilyichevsk $(7384 \mathrm{~km})$.

Variants of transportation of crystalline hydrates (NGH), LNG, CNG with coefficients of strength margin of ship gas transportation system $K_{\mathrm{m}}=2.5$ and 1.75 , and of renting ships for container shipments of compressed gas were considered. Results of calculations given in Tables 4 and 5, led to the following conclusions.

CNG transportation can unambiguously be recommended for servicing the Azov-Black Sea shelf. Capital investments and annual current costs are 1.5-2 times lower than with LNG.

At increase of shipment leg to $620 \mathrm{~km}$ (that includes all possible itineraries within Black Sea water area), the advantage of compressed gas over liquefied gas in terms of capital costs is 1.2 times, and current expenses become practically equal.

For cases related to going beyond the Black Sea limits through Bosporus, Dardanelles, and the more so beyond Mediterranean Sea limits through the Suez Channel, the variant of gas transportation in the liquefied state can be unambiguously recommended. With $200 \mathrm{~km}$ leg the capital investments still remain to be equal, but current costs drop by $10 \%$. With $3000 \mathrm{~km} \mathrm{leg}$ the capital investments and current costs decrease by $15 \%$, with more than $7000 \mathrm{~km}$ leg capital investments decrease by $40 \%$, and current costs - by $30 \%$.

1. (2012) Methane is the fuel of 21st Century! wzw. neoplan.ru / nevs / Metan. 16.05.2012.

2. (2013) How future gas-extraction in Ukraine is evaluated. Ukrainian power engineering 23.05.2013. http: / / ua-energy.org / post/32050

3. Karp, I.M., Eger, D.O., Zarubin, Yu.O. et al. (2006) State-of-the-art and prospects of development of oil-and-gas complex of Ukraine. Kyiv: Naukova Dumka.

4. Votintsev, A.V. (2007) Transportation of natural compressed gas. Gaz. Promyshlennost, 3, 62-63.

5. Ren, Ch.G., Zelenovskaya, E.V. (2011) Review of existing methods for transportation of natural gas for long distances and assessment of their applicability. Neft, Gas i Biznes, 3, 3-9.

6. (2006) Offshore transportation of natural compressed gas. Morskaya Birzha, 16(2), 65-69.

7. wrww.uh.edu/news-events/media-publications

8. Paton, B.E., Savitsky, M.M., Savichenko, A.A. (1995) Structure and technology of fabrication of high-pressure vessels. Avtomatich. Svarka, 9, 5-8.

9. Savitsky, M.M., Savitsky, A.M., Suprunenko, V.A. et al. (2013) Determination of parameters of lightweight steel vessels for cargo system of CNG-transportation. Visnyk NUK, 1, 4-14.

10. Paton, B.E., Kryzhanivsky, E.I., Savytsky, M.M. et al. Method of transportation of natural compressed gas by mobile pipeline: Declarat. Pat. on utility model 67664 Ukraine. Int. Cl. F17C 5/00. Fil. 08.12.11. Publ. 27.02.12.

11. Potak, Ya.M. (1972) High-strength steels. Moscow: Metallurgiya.

12. Makara, A.M. (1964) On uniform strength of highstrength steel welded joints. In: New problems of welding engineering. Kyiv: Tekhnika, 247-268.

13. Trufyakov, V.I. (1973) Fatigue of welded joints. Kiev: Naukova Dumka.

14. (2007) Rules for construction and safe service of vessels operating under pressure. Kyiv: Osnova.

15. (1989) Handbook on steel and alloy grades. Ed. by V.G. Sorokin. Moscow: Mashinostroenie.

16. Zinoviev, B.E. (1989) Thermophysical properties of metals at high temperatures: Refer. Book. Moscow: Metallurgiya.

17. Sterenbogen, Yu.A., Petrov, P.F. (1979) Effect of solidification temperature interval on susceptibility of steels to formation of solidification cracks during welding. Avtomatich. Svarka, 7, 10-13.

18. Savitsky, A.M., Vasiliev, V.G., Savitsky, M.M. et al. (2005) Influence of the heating stage on structure formation of welded joints on hardening steels. The Paton Welding J., 1, 15-17.

19. Savitsky, O.M. (2005) Influence of rapid heating on structure of carbon steels at local thermal action. Metaloznavstvo ta Obrobka Metaliv, 4, 33-35.

20. Gridnev, V.N., Meshkov, Yu.Ya., Oshkaderov, S.P. et al. (1973) Physical principles of electrothermal strengthening of steel. Kiev: Naukova Dumka.

21. Dudko, D.A., Savitsky, A.M., Savitsky, M.M. (1996) Gas metal arc welding with activating flux. Avtomatich. Svarka, 10, 54-55.

22. Paton, B.E., Savitsky, M.M., Gvozdetsky, V.S. et al. (2003) Application of active fluxes and active gases to increase efficiency of arc and plasma welding. The Paton Welding J., 5, 2-5.

Received 09.04.2014 